Niniejsza publikacja jest dostępna na licencji Creative Commons. Uznanie autorstwa-Użycie niekomercyjne-Bez utworów zależnych 3.0 Polska. Pewne prawa zastrzeżone na rzecz autora. Zezwala się na wykorzystanie publikacji zgodnie z licencja - pod warunkiem zachowania niniejszej informacji licencyjnej oraz wskazania autora jako właściciela praw do tekstu. Treść licencji jest dostępna na stronie: http://creativecommons.org/licenses/by-nc-nd/3.0/pl/

Lingwistyka Stosowana 21: 1/2017, 210-213

\title{
Sprawozdanie z konferencji naukowej Polskiego Towarzystwa Lingwistyki Sto- sowanej i Instytutu Komunikacji Specjalistycznej i Interkulturowej Uniwersy- tetu Warszawskiego Lingwistyka Stosowana. 35 lat PTLS, Warszawa, 15-16 kwietnia 2016 r.
}

W dniach 15-16 kwietnia 2016 roku w Warszawie odbyła się konferencja naukowa Lingwistyka Stosowana. 35 lat PTLS współorganizowana przez Polskie Towarzystwo Lingwistyki Stosowanej i Instytut Komunikacji Specjalistycznej i Interkulturowej Uniwersytetu Warszawskiego. Temat konferencji wyznaczył ramy dyskusji - oczekiwanej ze względu na potrzeby wskazania kierunków rozwoju nie tylko lingwistyki stosowanej, ale także lingwistyki czystej, translatoryki czy glottodydaktyki.

Uroczystego otwarcia dokonał prof. zw. dr hab. Sambor Grucza, przewodniczący Polskiego Towarzystwa Lingwistyki Stosowanej. Z kolei naukową część konferencji otworzył wykład prof. dra hab. Franciszka Gruczy, dra h.c. mult., członka rzeczywistego Polskiej Akademii Nauk. W swoim wystąpieniu prof. F. Grucza przywołał po krótce najważniejsze wydarzenia związane z narodzinami lingwistyki stosowanej w Polsce (a także na świecie) podsumowując jej dotychczasowe osiągnięcia i wyznaczając kolejne cele.

Po dyskusji i krótkiej przerwie na kawę dalsza część obrad odbywała się w sekcjach. Sekcję T1 otworzył referat prof. dra hab. Jerzego Żmudzkiego (UMCS) dotyczący próby określenia aktualnego statusu jako zjawiska i terminu ekwiwalencji translacyjnej. Dr Konrad Klimkowski (KUL) z kolei starał się określić rolę nauczyciela translacji w rozwoju sprawności funkcjonowania zawodowego przyszłych thumaczy. W dalszej części (po krótkiej dyskusji) głos zabrał dr Mieczysław Nasiadka (UW), który przywołał analizę wyników i główne problemy tłumaczenia konsekutywnego w wykonaniu zaawansowanego studenta kursu thumaczenia ustnego. Wystąpienie dra Mariusza Marczaka (UP) „Podejście interkulturowe a rozwijanie kompetencji translatorskiej”, zwieńczone krótką dyskusją, zakończyło pierwszą część obrad tej sesji panelowej, a jej uczestnicy udali się na lunch.

W sekcji L1 jako pierwsza głos zabrała prof. dr hab. Beata Mikołajczyk (UAM), która podjęła tematykę kontrastowania sieci rodzajów tekstów (specjalistycznych) jako zadania dla lingwistyki stosowanej. Dr hab. Jan Sikora (UG) poczynił kilka uwag na temat illokutywnej funkcji asertywów. Po krótkiej dyskusji dr Jan B. Łompieś (UW) wygłosił referat „Na marginesie metawiedzy i metakompetencji tekstotwórczej naukowca”, a dr Joanna Pędzisz (UMCS) - „Komentuj na blogu: interakcje w blogosferze jako przedmiot badań w analizie dyskursu internetowego".

Po przerwie w sekcji T2 mgr Monika Nader-Cioczek (UMCS) podjęła tematykę kompetencji tłumaczeniowej w ramach tłumaczenia a vista. Dr Emil Lesner (USz) 
zarysował problem przekładu tekstów melicznych na podstawie pieśni Wilcza zamieć i jej tłumaczenia na język niemiecki, a, po krótkiej dyskusji, dr Katarzyna Tryczyńska (UWr) zwróciła swoim wystąpieniem uwagę na problem asymetrii kulturowej w niderlandzkich i angielskich przekładach wybranych polskich powieści współczesnych. Wystąpienie mgr Agaty Kornackiej (UW) ,Jak daleko można zabrnąć w thumaczeniu? Analiza fragmentów poematu El gaucho Martín Fierro w przekładzie Henryka Mackiewicza”, po którym nastąpiła krótka dyskusja, zakończyło obrady w sekcji T2; uczestnicy udali się na przerwę kawową.

W sekcji L2 natomiast prof. dr hab. Krzysztof Nerlicki (USz) wygłosił referat: „Glosy frazeologiczne w słownikach niemiecko-polskich - propozycja ich dyferencjacji i uzupełnień na przykładzie Wielkiego słownika PONS”. Dr hab. Magdalena Lisiecka-Czop (USz) poddała analizie słowniki dwujęzyczne i ich użytkowników w świetle recenzji konsumenckich na portalach internetowych. Po krótkiej dyskusji dr Anna Bajerowska (UW) podjęła rozważania oscylujące wokół ontologii terminologicznych jako cyfrowych reprezentacji wiedzy. W optyce wystąpienia dra Marka Łukasika (AP) zaś pozostało minimum terminologiczne w nowej odsłonie.

Po krótkiej przerwie na kawę obrady w sekcji G1 otworzyły rozważania prof. dr hab. Urszuli Paprockiej-Piotrowskiej (KUL) na temat kompetencji narracyjnej w języku polskim jako obcym na przykładzie francuskojęzycznych dorosłych. Prof. dr hab. Przemysław E. Gębal (UW) przyjrzał się perspektywom glottodydaktyki polonistycznej na tle rozwoju glottodydaktyki ogólnej. Po krótkiej dyskusji mgr Anna Kijoch (UW) zwróciła uwagę na znaczenie i wpływ badań potrzeb językowych dla procesu nauczania języka polskiego jako obcego dla celów zawodowych, a dr Aleksandra Wiater (WSB) - na pomiar sprawności mówienia w komunikacji obcojęzycznej. Krótka dyskusja stanowiła podsumowanie pierwszego dnia obrad.

W sekcji L3 prof. dr hab. Artur Dariusz Kubacki (UP) przywołał główne założenia koncepcji pluricentryzmu w przekładzie terminologii niemieckojęzycznych odpisów z ksiąg wieczystych. Dr Edyta Więcławska (URz) podjęła zagadnienie operacjonalizacji wyboru ekwiwalentów terminologicznych w thumaczeniu angielskojęzycznych tekstów prawa. Po krótkiej dyskusji głos zabrała dr Justyna Alnajjar (UW) wystąpieniem „E-mail jako genre: badanie dyskursu korporacyjnego”. Dr Michał Wilczewski (UW) z kolei podjął problem kulturowych podstaw świadomości komunikacyjnej wśród osób pracujących w środowisku multikulturowym.

Obrady drugiego, ostatniego, dnia konferencji otworzył referat dr Anny Szafernakier-Świrko (UW): „Nauczyciel języków obcych XXI wieku Oczekiwania. Wyzwania. Perspektywy”. Następnie głos zabrał dr Artur Świątek (UP), który zajął się użyciem wybranych angielskich wyrazów leksykalnych i funkcyjnych przez polskich użytkowników języka drugiego na różnych poziomach zaawansowania. Po krótkiej dyskusji dr Agnieszka Andrychowicz-Trojanowska (UW) przywołała sposoby pracy ucznia szkoły średniej z podręcznikiem do nauki języka angielskiego w obrazowaniu okulograficznym. Mgr Sławomira Kołsut (UW) wspólnie z mgr Magdaleną Kalitą 
(UW) podjęły problematykę podejścia zadaniowego w kształceniu językowym uczniów w różnym wieku z perspektywy neurobiologicznej, prezentując zarazem koncepcje dwóch projektów badawczych. Po tym wystąpieniu uczestnicy sekcji, po krótkiej dyskusji, udali się na przerwę kawową.

W sekcji L4 jako pierwsza głos zabrała prof. dr hab. Ewa Żebrowska (UW) wystąpieniem na temat zachowania komunikacyjnego w dobie ery postdigitalnej. Dr Magdalena Filar (UP) poddała semantycznopragmatycznej analizie metafory konwencjonalne i kreatywne w dyskursie migracyjnym. Po krótkiej dyskusji dr Anna Szczepaniak-Kozak (UAM) wraz z drem Hadrianem Lankiewiczem (UG) przywołali wybrane aspekty mowy nienawiści w Polsce. Jako ostatnia w tej sekcji głos zabrała dr Magdalena Zabielska (UAM) poświęcając swój referat medycznemu opisowi przypadku w służbie lekarzom, studentom i pacjentom.

Po dyskusji i przerwie kawowej ostatnią część obrad sesji panelowych rozpoczęło w sekcji G3 wystąpienie dra Jacka Karpińskiego (UWr) dotyczące komunikacji na pokładzie samolotu (personel pokładowy-pasażer) jako problemu dla dydaktyki języków obcych. Dr Renata Nadobnik (PWSZ im. Jakuba z Paradyża) zajęła się istotą dwujęzycznych rozmówek językowych. Po krótkiej dyskusji mgr Urszula MajcherLegawiec (UJ) zajęła się przywołaniem założeń glottodydaktyczego modelu inkluzji na przykładzie ucznia cudzoziemskiego w polskiej szkole. Mgr Dorota Czerska-Andrzejewska (UJ) wygłosiła referat na temat: „Mall a samokształcenie produktywnych kompetencji leksykalnych studentów polskich uczelni”. Dr Elżbieta Gajek (UW) poświęciła swoje wystąpienie technologiom mobilnym w nauczaniu języków obcych w opinii nauczycieli języków obcych. Jako ostatni w tej sekcji głos zabrał 13:00 13:20 dr Marcin Łączek (UW), który dokonał przeglądu polskiej i angielskiej terminologii funkcjonującej w obszarze glottodydaktyki dwujęzycznej.

Referat dra Grzegorza Pawłowskiego (UW) poświęcony dowodom empirycznym pracy poznawczej tłumacza - autora polskich neologizmów specjalistycznych z zakresu hymnografii i muzyki bizantyjskiej otworzył obrady sesji panelowej L5. W optyce wystąpienia dr Joanny Osiejewicz (UZ) pozostawały prawnomiędzynarodowe aspekty tłumaczenia traktatów. Po krótkiej dyskusji dr Łukasz Plęs (UŁ) wygłosił odczyt pt.: „'Mowa w stanie oblężenia'. Cechy języka propagandy PRL w oparciu o komentarze Michała Głowińskiego". Dr Magdalena Białek (UWr) przedstawiła kilka refleksji dotyczących współczesnego dyskursu na temat kształcenia nauczycieli, a w szczególności oczekiwania glottodydaktyków wobec nauczycieli języków obcych. Dr Izabela Olszewska (UG) zajęła się niemieckojęzycznymi drukami ulotnymi jako formą komunikacji społecznej na przykładzie gdańskich materiałów efemerycznych. Odczyt mgr Anety Kwiatkowskiej (PAN BG) dotyczył struktury i języka reklamy w wybranych gdańskich drukach ulotnych i folderach handlowych okresu międzywojennego. 
Po krótkiej dyskusji w sesjach panelowych prof. Sambor Grucza podsumował i zamknął konferencję otwierając jednocześnie Walne Zgromadzenie Polskiego Towarzystwa Lingwistyki Stosowanej.

Konferencja była okazją do interesującej wymiany spostrzeżeń i poglądów naukowych pomiędzy językoznawcami, translatorykami i glottodydaktykami, a obecność wybitnych autorytetów jej niezwykle cennym dopełnieniem. Składam podziękowania dla Komitetu Organizacyjnego oraz wszystkich osób zaangażowanych w jej organizację i prace związane $z$ wydaniem planowanej monografii pokonferencyjnej. Na koniec, warto nadmienić, iż decyzją przewodniczącego Polskiego Towarzystwa Lingwistyki Stosowanej prof. Sambora Gruczy uczestnicy jubileuszowej konferencji, będący zarazem członkami PTLS, nie ponosili opłat tytułem uczestnictwa.

Marcin LĄCZEK Uniwersytet Warszawski 